\section{Reform and Innovation:} \section{Ukraine's New Private Universities}

\section{Joseph Stelar and James Stocker}

Joseph Sterar is associafe professor of education at Seton Hall University in New Jersey James Stocker is a graduate student in the higher education progrom. Address: College of Education, Seton Hall University, South Orange, New Jersey O7079, USA.

Higher education in Ukraine - as well as many other countries comprising the former Soviet Union-is undergoing its second revolution of the 20th century. The first took place in 1917 and accelerated in the years following World War II, especially under Josef Stalin, who imposed a socialist and Russified system of higher education upon Ukraine and the other Soviet republics. Ukrainian higher education throughout much of the 20th century lacked the intellectual pluralism - particularly in the social sciences and humanities-essential for institutional vitality due to the ideologically oriented, strong central planning, control, and demands for academic orthodoxy.

The second revolution is currently underway in Ukraine. This revolution seeks to restructure higher education radically and profoundly. It seeks to alter substantially, if not eradicate, the official state dogmas through a more pluralistic approach. Driven hy newly introduced powerful market forces the Russifiedhigher education system is increasingly viewed as irrelevant to the needs of an independent Ukraine.' This is the context in which Ukrainian private higher education finds itself in the 1990 s.

\section{As of May 1996, nearly fiveyears after Ukrainianindependence, the number of licensed private colleges and universi- ties exceeded 120.}

As of May 1996, nearly five years after Ukrainian independence, the number of licensed private colleges and universities exceeded 120. These institutions, which enroll about 2 percent of the country's 800,000 college students, have the potential to fill the gaps in the Ukrainian national system of higher education. Ukrainian private institutions of higher education are responding to the rapidly changing economic conditions. Through curricular innovations in business, law, education, and medicine these institutions are responding to the academic, economic, religious, and cultural needs of the newly independent and democratiz- ing society.

Since the emergence of an independent Ukraine in December 1991, dramatic social, religions, and cultural changes have also encouraged the proliferation of private institutions. Linguistic and religious groups, buoyed by the increased freedoms, have expressed interest in establishing private institutions of higher education to further religious or cultural goals. For example, the Greek Catholic Church and other religious groups, especially in western Ukraine, sought (unsuccessfully)to secure a license from the state to establish private institutions. Indications are they may renew such initiatives in 1997. Similarly a new institution, the International Christian University, has began operations in Kiev, ,

The majority of Ukraine's private institutions are located in the eastern and southern sections of Ukraine around the cities of Donetsk, Zaporozhje, Kharkov, and the Republic of Crimea, which are home to about 11.5 million ethnic Russians in Ukraine. In the nine Ukrainianspeaking regions in the west and north there are only a few private universities. Moreover, in such important Ukrainian-speaking areas as Volynskaya, Chernovitskaya, Nikolayevskaya, and Uzhgorodskaya there arc no private institutions of higher education. Even in Kiev, which is the center for the Ukrainian private higher education movement, only the public Kiev Mohyla-Academy, appears to fully use Ukrainian as the language of instruction. Ironically, it appears that state policies of the early 1990s that sought to increase the usage of Ukrainian as the medium of instruction and provide more Ukrainian content in higher education actually spawned the establishment of Russian-language and culturally oriented private universities as havens for the sizable number of Russian-speaking inhabitants.

\section{FINANCING PRIVATE HIGHER EDUCATION}

Under current regulations the Ukrainian government classifies all private universities as for-profit organizations, and taxes their income (e.g., tuition, fees, grants) at a rate of about 70 percent. In addition to paying these onerous taxes private institutions need to support daily operations, meet standards for state-controlled licensing and accreditation, and cope with the old Soviet administrative command- and control-philosophy practiced in the Ministry of Education.

It is within this context that the initial surge in the development of private higher education is rapidly giving way to financial realities. The need to rationalize the system, avoid duplication, and coordinate efforts suggeststhat numerous institutional consolidations and closings arc on the horizon. The Darwinian theory of private higher edu- 
cation institutions is evident, and there will soon be a major shake-up in that sector. Unless Ukrainian private higher education receives technical assistance with planning, begins to form appropriate consortial arrangements among its members, and can fashion more favorable relations with the Ministry of Education, it is in greater danger of extinction than overdevelopment.

\section{Undercurrent regulations the Ukrainion government classifiesall private univer- sities a5 for-profit organizations, and taxes their income (e.g., tuition, fees, grants) at a rate of about 70 percent.}

Direct financial support for private higher education from the national government in Kyiv is virtually nonexistent, and public policy defining such support is unclear. Even though "theministry states that government policy generally precludes the provision of direct financial support to private higher education, there is considerable evidence that a handful of private universities in the Kyiv region are receiving indirect government support through subventions to provide virtually free instructional and administrative space. It is not clear why some institutions are granted this indirect but important support while others are denied it. The fundamental question "what is the public policy for state funding of private higher education?" remains unanswered.

Several private higher education institutions outside Kyiv have also been able to secure support from local (e.g., city, regional) government authorities. The support from local government frequently takes the form of indirect subsidies such as providing relief from local taxes and provision of instructional facilities. In other instances, private institutions contract with local government to provide educational services in exchange for direct financial support. The Donetsk Humanitarian Institute, for example, received a direct appropriation from the city government in return for providing educational services to school teachers.

Though local government financial support for private higher education is still rare, several factors in the relationship between higher education and local authorities may encourage an expansion of this form of subsidy. Historically, higher education policy and governance have been directed by the central government in Kyiv and local authorities had little sense of responsibility or ownership. Private higher education initiatives to identify and fill local education gaps are often looked upon quite favorably, if not protectively, by local authorities. This is especiallytrue in cities inadequately served by the traditional postsecondary education system directed by the Ministry of Education in Kyiv.

\section{GOVERNANCE OF PRIVATE HIGHER EDUCATION}

Governance of private higher education in Ukraine is understandably directed to seeking and maintaining autonomy from the central administration of the state and its Ministry of Education. Minimizing state microregulation is a complex and delicate process, as private universities are dependent on the state for licensing, accreditation, and possible future tax abatements, if not direct support.

However, the state, continues to enforce the old Soviet-style ideology challenging moves toward self-governance. For example, the legislation passed in 1996 grants the state full authority over the approval of private higher institutions, their charters, and leadership. While private institutions are vigorously opposing this legislation, the heavy hand of the state is felt most forcefully,

Though local government financial suppart forprivate higher education is still rare, several factors in the relationship between higher education and local authorities may encourage an expansion of this form of subsidy.

\section{CONCLUSION}

The future of Ukrainian private education is far from certain. Many questions need to be addressed. Can Ukrainian private higher education survive without financial support from the state? How should private institutions negotiate with the central government while offering an alternative to the state monopolized institutions.

Nevertheless it is evident that the emerging Ukrainian private sector of higher education has made its presence felt. By its example, private higher education is, in turn, making the entire Ukrainian system of higher education stronger, more flexible, and more responsive.

\section{NOTE}

1. E Swing and F, Orviel, "Educationin a New Europe," Comparative Education Review 36, no. 1 (February 1992):1-9. Also see J. Stetar, "Private Higher Education and Extemal Control," in The State and School, ed. J. Tumer (London: Falmer Press, 1996) 